\title{
REVIEW OF THE ECONOMIC LEGISLATION IN MARCH 2013'
}

\author{
I.Tolmacheva, Yu.Grunina
}

In March, the following amendments were introduced in the legislation: the list of federal state institutions of higher vocational training which independently set educational standards was supplemented; amendments concerning concession holders which manufacture goods, fulfill work and render services at regulated prices were introduced; the value of the subsistence level per capita in the $4^{\text {th }}$ quarter of 2012 was determined.

\section{Orders of the President of the Russian Federation}

Order No. 209 of March 19, 2013 on AMENDMENT OF THE LIST OF FEDERAL STATE INSTITUTIONS OF HIGHER VOCATIONAL TRAINING WHICH INDEPENDANTLY SET EDUCATIONAL STANDARDS AND REQUIREMENTS TO EDUCATIONAL PROGRAMS OF HIGHER VOCATIONAL EDUCATION WHICH THEY CARRY OUT

An amendment was introduced into the list of federal state institutions of higher vocational education which independently set educational standards and requirements to educational programs of higher vocational education which they carry out; the above list includes seven federal professional state educational establishments: M.V. Lomonosov Moscow State University, St. Petersburg State University, N.E. Bauman Moscow State Technical University, St. Petersburg State Naval Technical University, Russian Presidential Academy of National Economy and Public Administration, Peoples' Friendship University of Russia and the Moscow State Institute of International Relations (University) under the Ministry of Foreign Affairs of the Russian Federation.

According to the amendment introduced, the above list was supplemented with item 8 which specifies that the Financial University under the Government of the Russian Federation will independently set educational standards and requirements to educational programs of higher vocational education which it carries out.

\section{Resolutions of the Government of the Russian Federation}

1. Resolution No. 231 of March 18, 2013 on AMENDMENT OF THE STANDARD CONCESSION AGREEMENT AS REGARDS PUBLIC UTILITIES INFRASTRUCTURE SYSTEMS AND OTHER PUBLIC UTILITIES PROJECTS, INCLUDING FACILITIES FOR WATER, HEAT, GAS AND POWER SUPPLY, WATER DISPOSAL, WASTE-WATER TREATMENT AND RECYCLING (DISPOSAL) OF DOMESTIC WASTE, INSTALLATIONS MEANT FOR LIGHTING OF AREAS OF URBAN AND RURAL SETTLEMENTS, PROJECTS MEANT FOR LANDSCAPING OF TERRITORIES, AS WELL AS SOCIAL AND DOMESTIC FACILITIES.

A concession holder of the public utilities infrastructure system and other public utilities projects is obligated to raise such a volume of investments for financing an investment program as is specified in the concession agreement even in case the investment program has been modified. With termination of the agreement, the concessor has to ensure a return of the investment capital to the concession holder within the period specified in the agreement, except for the investment capital whose return was taken into account in setting of tariffs on goods (jobs and services) of the entity which carries out hot water and cold water supply or water disposal.

A respective provision concerning concession holders which produce goods, fulfill jobs and render services at regulated prices is included in a standard concession agreement on granting into concession of the above facilities approved by Resolution No.748 of December 5, 2006 of the Government of the Russian Federation.

1 The review was prepared with assistance of the KonsultantPlus legal system. 
2. Resolution No.227 of March 18, 2013 on SETTING OF THE VALUE OF THE SUBSISTENCE LEVEL PER CAPITA AND BY MAIN SOCIAL AND DEMOGRAPHIC GROUPS IN GENERAL IN THE $4^{\text {TH }}$ QUARTER OF 2012 IN THE RUSSIAN FEDERATION

The value of the subsistence level is determined quarterly on the basis of the consumer goods basket and the data on the level of consumer prices of food products, non-food products and services and expenses related to mandatory payments and fees. In the $4^{\text {th }}$ quarter of 2012 , the value of the subsistence level per capita was determined in the amount of $\mathrm{Rb} 6,705$, while that for the disabled, pensioners and children, in the amount of $\mathrm{Rb} 7,263$, $\mathrm{Rb} 5,281$ and $\mathrm{Rb} 6,432$, respectively. 